\title{
Analysis of Top Design and Floor Design on Tortor Batak Toba Motion
}

\author{
Yusnizar Heniwaty ${ }^{1}$, Sitti Rahmah ${ }^{2}$, Iskandar Muda ${ }^{3}$ \\ 1,2,3 Universitas Negeri Medan, Indonesia \\ Email: yusnizarheniwaty@unimed.co.id
}

\begin{abstract}
This study focuses on Tortor Batak Toba in relation to the social understanding of the supporting community, which is motivated by documentation in the form of writing, video, and other forms that are not recorded and accurate. The research method used is a qualitative descriptive approach and the location of the study in dance study program Sendratasik Department. Data collection methods are carried out with documentation and interviews. The results shows that the structure analysis of Toba Tortor Batak motion form was formed from the top design namely vertical design, horizontal design, pure design, static design, straight design, medium design, and floor design that is straight design, as well as learning design of imitation motion tortor dance.
\end{abstract}

Keywords: Tortor Batak Toba; structure; top design; floor design; documentation

\section{Introduction}

Tortor is a performance that reflects the lifestyle of the Toba Batak people, which is always present in ceremonial activities, whatever the form of ceremony, such as the tonggul panaluan tortor, saoan tortor performed at the treatment ceremony, tortor at the saur matua ceremony, mangido udan paramean in the mangido udan ceremony, martumba tortor and so on.

In this series of ceremonies, the presentation of tortor is accompanied by traditional music of Batak Toba gondang sabangunan or gondang hasapi (a set of traditional Batak Toba instrument names). For Toba Batak community, the presentation of tortor with gondang must be available, because without gondang, tortor presentation cannot be made. Both become an integral and inseparable part in the series of ceremonial activities that are always carried out by the Toba Batak tribe. In its implementation, there are provisions in manortor that are in accordance with gondang which played. All of these have become a benchmark in the implementation of each ceremony.

Tortor become a traditional dance owned by Toba Batak tribe. Toba Batak Tortor is a dance that shows the life journey of the Toba Batak tribe that shows courage, loyalty, and authority, and they make tortor as material in various activities. Toba Batak Tortor is a dance that has a format in its presentation, which has a characteristic on urdot (leg motions performed with a count of 2 beats) which at a glance is easy to do. But actually the movement that characterizes the Toba Batak tortor is actually very difficult to do, because the coordination between the leg motions and hand motions, especially the different beats and counts, makes this dance interesting. In addition to urdot motions, Toba Batak tortor also do a lot of sombah motions by bowing their heads with sombah upwards which is an expression of petition, gratitude for Debata Mula jadi nabolon. A series of one-to-another motions, from the first arrangement to the end has a story line and a message from the creation of the Toba Batak tortor. The musical accompaniment that is a benchmark in dance, also becomes an accompaniment that gives a sense to the dancer (panortor). 
In its development, tortor is not only done in the seven gondang format, according to the customary rules. The artists expressed their creativity by rearranging the Toba Batak tortor with variations in motion and floor patterns that were different from the beginning, both from the number of dancers, floor patterns, themes, and so forth. The changes in performance and the purpose of the implementation made the Toba Batak tortor increasingly known, but on the one hand, many creations did not match the format, this was also supported by the choreographer / choreographer's disregard for the values that existed in tortor.

The changes in tortor performances are unwittingly followed by many studios on the grounds that there are orders that ask in accordance with the wishes of the audience, so that creation becomes a reason in its development. On the one hand the emergence of the creativity of the artists made the Batak Toba dance documentation more diverse, but on the other hand, creativity without a basic understanding of the art that was developed made the work change far from what was desired by the community owner.

The change in the Toba Batak tortor performance gives a positive impact on the development of the Toba Batak traditional dances. Batak Toba community is more or less paying attention to the development of traditional Batak arts, including the tortor by organizing events that include Toba Batak tortor as a program material. But from the changes and developments in the performance, there are still many artists who do not understand the contents of Toba Batak tortor, so that in the performance they cannot do their best according to the format.

As a cultural heritage, Toba Batak tortor deserves attention, because many of the values of the performance give a message about the meaning of loyalty, brotherhood, struggle, and authority which are attitudes in human life that must be possessed. Based on the above review, many things need to be studied to provide an understanding of life that can be observed from the composition of the dance, the form of motion that gives the true meaning of tortor presentation, supported by elements in dance that are interrelated with one another, as well as aesthetic expressions which expressed norms of rules into the performance.

If this assumption is true, then it is also true that traditional art is increasingly apprehensive. This applies to all traditional arts, not to mention the tortor in Toba Batak community. Until now, Indonesian traditional art is still a concern of Western nations. It means that the only property of the Indonesian people that is still sold is traditional culture and art. Bastomi (1992: 45), explains that traditional art is a form that is sourced and rooted and has been felt as belonging to the community itself, its processing is based on the ideals of the supporting community. Thus the traditional arts are the result of the activities of a group of people carried out in a sustainable manner, so that it becomes a tradition for them

Basically, traditional art stems from the existence of ritual needs that are usually raised in a motion, sound or certain actions in a ritual ceremony. While the process of creation there is a relationship between the subject of the creator and the conditions of the environment.

The thinking underlies this study, which assumes that tortor have relationship with the social system that grows and develops in their society. Where the provision must be structured according to the custom system. From this view, it is known that there are several designs in analyzing the structure of the Toba Batak tortor which support the integrity of the dance. This design analysis shows that the tortor becomes a unity of the community in living a social life, as stated in the top design and floor design. There are generally two basic lines on the floor, that is straight lines and curved lines, and circular lines. Straight lines can be made forward, backward, 
sideways or oblique, straight lines give the impression of keen and are mostly done on traditional forms of dance in North Sumatra, especially the Batak tribe. Curved lines are made in a semicircular position or the opposite of semicircles, triangles, rectangles, the letter $\mathrm{T}$ and the opposite, and also zigzag design. The circular line becomes the main line in the tortor besides the straight line. (Hasan Waliono, 1992: 157) also explained, circle lines are widely used in primitive dances and in communal dances. This explanation reinforces that in general circle lines, straight ines are the dominant patters I traditional dance.

Based on the empirical conditions and assumptions as mentioned above, this study seeks to reveal in depth the Toba Batak tortor motion structure that is analyzed based on the design in tortor.

This study aims to reveal in depth about the structure of tortor motions in Toba Batak community in general, and specifically aims:

1. Identify the Toba Batak tortor's motions

2. Analyze the form of the top design and floor design

\section{Review of Literature}

For a long time Western scholars, Indonesian, anthropologists, Toba Batak artists saw the uniqueness of the Batak tribe culture, through them and other writers, making the Batak traditional dances often found in their writings. Although not written comprehensively, the contributions made make clarity the existence of the Toba Batak traditional dance.

Pandiangan (2014), in the thesis "totor" in the Batak Toba Sub Ethnic Marriage Ceremony in Balige District" explained that Tortor is a Batak dance that has its own privileges, besides having the uniqueness of conveying in dance, it also becomes a process of giving and receiving in the Batak kinship system, thought nonverbal communication, using symbols in disclosure. This understanding is important, because tortor is seen not only from its form but how the community makes tortor in their lives generations. Dance has a meaningful symbol in accordance with the provision in the Toba Batak customs which are manifested in the form movement, clothing, and circulation patterns. In addition to movement, music or Gondang used in tortor becomes one unit and reinforces the meaning of the symbols conveyed.

\section{Research Method}

The study was conducted by using several stages, from the collection of literature study data, observations and interviews, which were then inventoried, and identified for later processing and analysis based on qualitative methods, as material in finding answers to problems. Endraswara (2011: 44) explains that the qualitative method of phenomenology is based on four truths, namely sensual empirical truth, logical empirical truth, ethical empirical truth, and transcendent empirical truth.

The qualitative approach used was aims to describe the concept of Toba Batak community placing Tortor in their various activities. To obtain accurate data and information in this study, field research was conducted through interviews with resource persons who can provide information. This descriptive Research locations were carried out in Medan and Dance Education Study Program Universitas Negeri Medan by collecting data through observation, disclosure (interview) and testing (documentation).method is used in analyzing the structure of the Toba Batak tortor in Toba Batak community. 


\section{Discussion}

\subsection{Research Tortor}

For Toba Batak community, Tortor have an important role in their life activities, related to the spiritual life and also for social relations, which are placed with its purpose. In the context of custom, tortor is placed according to the position of each role in the custom system (dalihan natolu). Daliban Natolu consists of Hula-bula (the wife's giver), Boru (the wife's family), Dongan Sabutuba (family members in the life of Toba Batak people). Dancers in Toba Batak community are commonly referred to as Panortor.

Tortor is an individual, cultural and religious expression. The four standard hand motions (positions) in Toba Batak Tortor, according to the position of the dancer (Panortor) in the kinship system in the life of Toba Batak community, Maneanea means asking for blessings (bearing the burden), mamasu-masu means giving blessings, mangido tua means asking and receiving blessings and manomba means worshiping and asking for blessings. Lumban Tobing explains about tortors (in Thesis, Sannur, 2014).

a. Pangurdot: movement of the whole body, focus of motion on the soles of the leg, heels and body. The tip of the leg moves up, then down to the rhythm of the gondang, and the shoulder moves slowly left and right.

b. Pangeal: body movements on the waist and shoulders (sasap), left and right. This movement is related to the pangurdot movement.

c. Pandenggal: graceful movements of the whole body are focused on the movements of the arms, palms and fingers. Both open palms are lifted up slowly, then lowered down gracefully. Then both hands move forward in a semicircular motion, which rests under the chest. Simultaneously with that movement all the fingers move open and closed parallel to the plane of the palm.

d. Siangkup na (siakkup na): neck movements. The movements are in tune with the gondang and urdot mentioned above. Siakeup na, which literally means "extra", is not merely a distraction. Movement of the siakkup na is a form of expressing the soul of dance.

e. Hapunan: the expression of the face of a panortor (dancer). As one of communication with the audience.

\subsection{Tortor Structure}

The structure of the presentation of traditional tortor in Toba Batak community is commonly called Sipitu Gondang Tortor which is performed in every traditional party which is always done in every event. The composition of Sipitu Gondang Tortor starts from, 1) tortor mulamula, 2)tortor somba, 3) Tortor Mangaliat/Siuk-siuk, 4) Tortor Sibane-bane, 5) Tortor Saudara/Parsaoran, 6) Tortor Simonang-monang, 7)Tortor Hasahatan-Sitiotio. These seven tortor are the stages in each tortor presentation, with the positions of tortor 1, 2, 6, and 7 being the tortor that must exist, and the position of tortor 3, 4, and 5 are tortor that can change according to the context of custom activities. The form of Toba Batak tortor consists of movements that give meaning and purpose, which are carried out in accordance with the agreement of Dalihan Natolu as a customary system that is obeyed. Significant / meaningful motion is found in the whole range of Toba Batak tortor motions. Judging from the form of the performance, tortor is divided into women's movements and men's movements. Women's movements consist of tangan dibutuba motions, Bungka tangan motions, Ampe di abara, Rap udur juruk tu jolo, Margolom-golom masak. ${ }^{1}$. Men's movements consist of tangan dibutuba, Mangaot-aothon tabina, Marsantabi dibobina, Marnaek mijur bubut talak. This range of

\footnotetext{
${ }^{1}$ (Hutasoit, 1976: 16)
} 
motion becomes a standard motion and are always present in every custom tortor with a standard arrangement as well.

\begin{tabular}{|c|c|c|}
\hline No & $\begin{array}{c}\text { Description of } \\
\text { Movement }\end{array}$ & Design \\
\hline 1 & $\begin{array}{l}\text { Hand movements are } \\
\text { dibutuha. the movement } \\
\text { starts all tortor. For woman } \\
\text { motions, the position of } \\
\text { the hands is placed on the } \\
\text { stomach, right hand above } \\
\text { the left hand. The men } \\
\text { motions with both hands } \\
\text { get ready }\end{array}$ & $\begin{array}{l}\text { The hand is } \\
\text { dibutuba } \\
\text { Flat design }\end{array}$ \\
\hline 2 & $\begin{array}{l}\text { Movement is done slowly } \\
\text { moving up and down. } \\
\text { This movement illustrates } \\
\text { that panortors respectfully } \\
\text { respect all those present at } \\
\text { the ceremony. }\end{array}$ & $\begin{array}{l}\text { Marsantabi } \\
\text { diparateatean } \\
\text { (somba debata) } \\
\text { Horizon desigt }\end{array}$ \\
\hline & $\begin{array}{l}\text { This position can be done } \\
\text { only with standing } \\
\text { patterns, but there are also } \\
\text { those who do it with } \\
\text { variations in sitting } \\
\text { patterns }\end{array}$ & $\begin{array}{l}\text { Somba mula- } \\
\text { mula } \\
\text { Horizon } \\
\text { design, verti }\end{array}$ \\
\hline 3 & $\begin{array}{l}\text { This movement is carried } \\
\text { out after marsantabi } \\
\text { parateatean } \\
\text { Hands open and moved } \\
\text { alternately right hand and } \\
\text { left hand. } \\
\text { After marsantabi dibobi } \\
\text { movement continued with } \\
\text { the marnaek mijur bubut tala } \\
\text { movement }\end{array}$ & $\begin{array}{l}\text { marsantabi } \\
\text { diparateatean } \\
\text { (Woman) } \\
\text { parsantabi } \\
\text { dibobina } \\
\text { (Woman) }\end{array}$ \\
\hline
\end{tabular}




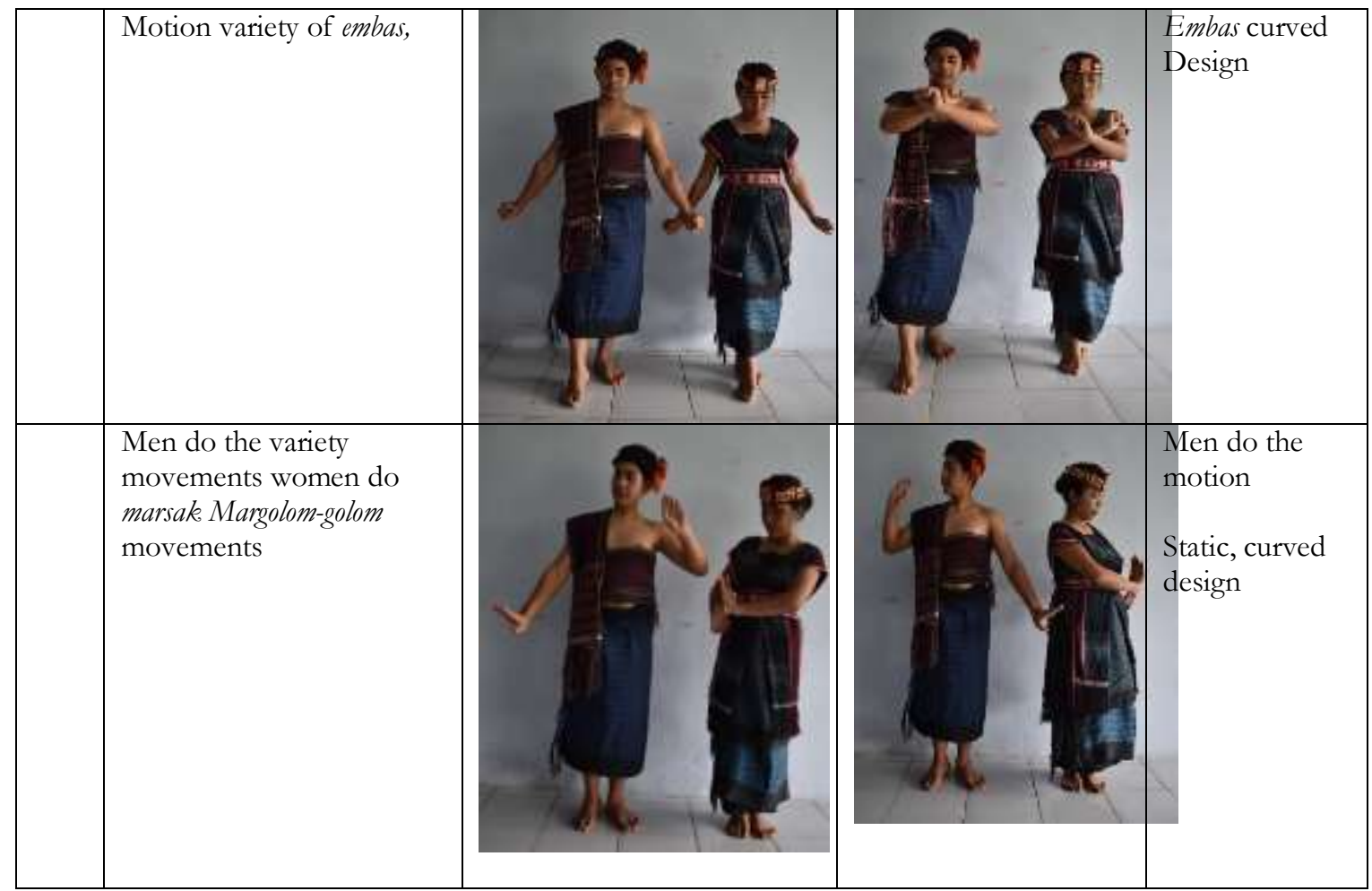

\subsection{Top design and floor design}

There are 10 patterns of motion in Toba Batak tortor series, the pattern of hand dibutuba movements with the form of hand motions in front of the stomach, the leg make mangurdot motion depicted in each range of motion 1 to 10 . Especially for the motion of mangurdot which forms the foundation in manortor and characterizes the tortor's motion. In Marsantabi dibobina 3, 6, 10 pattern that is with hand motif swung to the right side with fingertips pressed together like cupped, the phrase count 1-8 is done with a moderate count with a static design sentence. The pattern of pounding the thigh in a variety of 4 with the motive position is still lined with the body bends down and the elbows are placed on the thighs, with the phrase count done as much as $2 \mathrm{x}$ 8 with a moderate count, the sentence there is a symmetrical design on the legs and thighs and a contrast design on the position of the arm. The footing pattern on the motion range of 5,16 with the motive position of the body leaning upward and both hands down in a crossed position, the phrase footing pattern is done with a count of $2 \times 8$, with a low design sentence on the dancer's waist. Sibane-bane tortor pattern on variety motion of Marsantabi dibobina is calculated at a count of 1-8 and carried out repeatedly with the motive position of the walking or mangurdot in a place with the direction of the body being rotated to the right and left. The hands make a circular pattern in front of the chest (for men) and for women arrogant movements, mangurdot legs, with phrases performed in counts of 1-4. With the design sentences in on the leg. The pattern of Marnaek mijur bubut talak is found in mangaliat / Siuk-siuk tortor for movement 1-8 with standing body, body slightly bent, both hands make circular motion up and down above.

From the pattern of motion above, it can be seen that the design performed in dancing consists of the top design and the floor design. Furthermore, the design pattern can be changed according to the wishes of the position where they danced/manortor, for example the direction facing panortor facing the house of the executor of the activity, then the direction of facing can be turned away. Likewise, when panortor moves forward, then the movement can be changed to backward or back and forth. Based on the motion analysis, Toba Batak tortor has a top design that uses a flat design with the body standing upright facing with both hands cupped in front of the 
stomach. Besides using a design with Marsantabi dibobina movement carried out by male panortors. Then the vertical design when the arms extend up or down with the motion of margolom-golom masak, horizontal design when the limbs are more toward the horizontal.

From the pattern of motion above, it can be seen that the design performed in dancing consists of the top design and the floor design. Furthermore, the design pattern can be changed according to the wishes of the position where they danced/manortor, for example the direction facing panortor facing the house of the executor of the activity, then the direction of facing can be turned away. Likewise, when panortor moves forward, then the movement can be changed to backward or back and forth. Based on the motion analysis, Toba Batak tortor has a top design that uses a flat design with the body standing upright facing with both hands cupped in front of the stomach. Besides using a design with Marsantabi dibohina movement carried out by male panortors. Then the vertical design when the arms extend up or down with the motion of margolom-golom masak, horizontal design when the limbs are more toward the horizontal.

\subsection{Floor Design}

Floor design used in tortor is not diverse, the existing floor design consists of only 2 patterns namely a straight design and a circular design. When observed these two designs are very simple, but have expressions that are loaded with religious meaning and community obedience. The composition or pattern of tortor floor, created in a single line from the beginning to the end of the dance. This pattern is very simple and becomes a pattern that also exists in traditional dances in other Batak regions, as well as traditional dances in other tribes in Indonesia. The floor design on a tortor is not just a pattern arranged in one line, two lines or three lines, this line pattern is created meaningfully with an obedient, determined, and calculating attitude obtained based on deliberations on various issues, and how the community resolves them. The meaning of this line pattern also means that wisdom must go through a round of agreement to get to a goal.
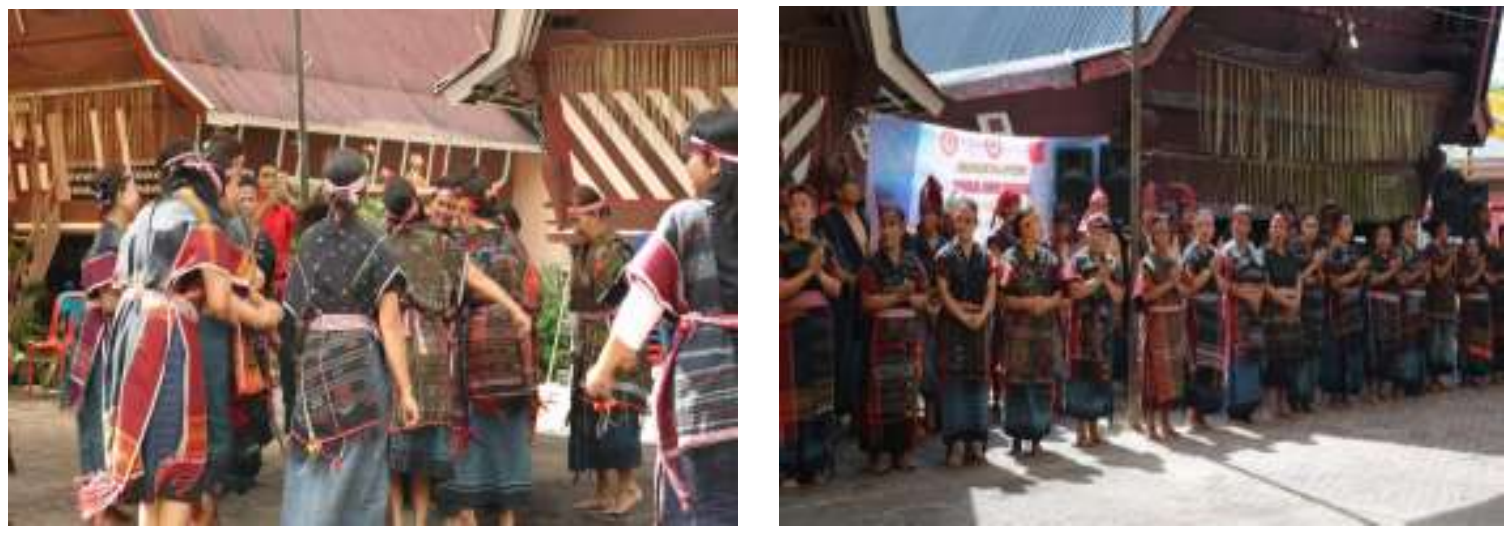

Floor design in circle pattern and straight line pattern

Based on the results of the analysis of the top design and floor design of Toba Batak tortor, it is known that the overall vertical floor design is found in the motion pattern of Rap udur juruk tu jolo, Mangaot-aothon tabina, with several directional positions facing in the manortor. Meanwhile the horizontal design forms a straight line with a position lined to the side, forward, rectangular. The straight design on Toba Batak tortor can be done differently in each customary activity according to the purpose of its implementation, but still forms straight, angular patterns that give meaning to compliance, harmony. 
The result of this research is also scientific evidence of the importance of understanding traditional arts, especially tortor which in a variety of motions is very simple and not diverse, but what must be understood is the meaning of each of the patterns of movement that requires it to be understood, so its development can be accepted by the community. Thus the process of inheritance and preservation can be carried out.

\section{Conclusion}

Toba Batak Tortor is a traditional dance originating from Toba Batak community and is not just a dance, but is a form of life of Toba Batak community. Based on data analysis, it can be concluded that there is a unity of movement which is arranged in a variety of motion patterns and forms the structure of the Tortor, with its presentation divided into 7 stages of the tortor. The unity of motion is arranged into a unified dance movement that forms the structure of dance movements consisting of motifs, phrases, sentences and patterns. From the analysis of motion patterns there are 10 patterns of motion for men and women. From these 10 patterns of motion, it forms the floor design and top design. The top designs that are formed are vertical design, horizontal design, pure design, static design, straight design, angular design, and medium design. While the floor design that is formed as a whole is a straight design.

\section{References}

Bastomi, Suwadji. (1992). Seni dan Budaya Jawa. IKIP Semarang Press. Semarang. Hadi, Y., S. (2012). Koreopgrafi: Bentuk-Teknik-Isi. Ed rev 2015. Yogyakarta: Dwi Quantum.. Jurnawan, H. (2015). Analisis Struktur Gerak Tari Jepin Langkah Penghibur Pengbibur di Kota Pontianak Kalimantan Barat. Universitas Tanjungpura.

Kartika, M., S. (2015). "Struktur Gerak Tari Tupai Jonjang di Kanagarian Lumpo Kecamatan IV Jurai Kabupaten Pesisir Selatan”. 13 Desember 2015.

Murgiyanto. (1992). Koreografi. Jakarta: PT. Ikrar Mandiri Abadi

Meri, L. (1968). Dance Composition, The Basic Elements. Terjemahan Soedarsono. Yogyakarta: Lagaligo.

Pandiangan (2014), "Tortor dalam Upacara Perkawinan Sub Etnis Batak Toba di Kecamatan Balige" Tesis di Program Pengkajian dan Penciptaan Seni Pertunjukan Pasca Sarjana, Universitas Sumatera Utara.

Sinaga, S. (2014). "Tortor dalam Pesta Horja Pada Kehidupan Masyarakat Batak Toba uatu Kajian Struktur dan Makna”. Tesis. Universitas Sumatera Utara. Medan.

Waliono, Hasan. 1992. Koreografi. Jakarta. PT. Ikrar Mandiri Abadi.

http://ejournal.unp.ac.id/index.php/sendratasik/articl/view/

$3381 / 1994$. 